\title{
A Good Death in Ratnapura : A Qualitative Study.
}

${ }^{1}$ Perera M.C., ${ }^{2}$ Ramadasa U., ${ }^{3}$ Chandrasiri G.M.L.W., ${ }^{3}$ Thaibudeen M.A., ${ }^{3}$ Kalupahana K.M.S.N. ${ }^{1}$ Consultant ENT, Head \& Neck Surgeon, ${ }^{2}$ Consultant Physician, ${ }^{3}$ Medical Officer, General Hospital, Ratnapura

\section{Introduction}

One of the most important goals of medical care in patients having a life limiting illness is achieving a "good death". To achieve this, components of a good death should be identified.

\section{Objectives}

To identify the components of a good death in Ratnapura, Sri Lanka.

\section{Methodology}

A qualitative, prospective serial study was done. The study sample included patients diagnosed as having life limiting illness and being followed up at the ENT, Palliative care and Oncology units at General Hospital Ratnapura.

\section{Results}

There were 42 participants in the study. Thirty five $(83.33 \%)$ of the patients had cancer and $7(16.67 \%)$ had non cancer life limiting illnesses. The study identified attributes which fall to 15 categories as common components of "good death".

\section{Conclusion}

The main categories of good death in Ratnapura, Sri Lanka, were having a good family relationship, having a good relationship with medical staff, Not being aware of death, Fighting against the disease, Dying at ones favourite place, Having faith, Maintaining hope, Maintaining dignity, Freedom from Pain, Physical \& Psychological symptoms, Not being a burden to others and Maintaining sense of control. Home was considered the best place to die.

\section{Keywords}

Good death, end-of-life care, quality of death and dying, Palliative care

\section{Introduction}

Death has been a subject which has been contemplated often in the Sri Lankan society especially due to its influence of Buddhism. In the Western world death is regarded as a function of old age, a consequence of the failure of modern medicine to hinder or preclude the inevitable, or as a process that can be prevented, reversed, or prolonged ${ }^{1}$. Research findings suggest that contemporary attitudes towards death and dying reflect a degree of trepidation, fear, and denial ${ }^{2-4}$. The term "Good Death" was originally used to describe the act of euthanasia. Currently in palliative care management in the Australasia region euthanasia is not considered as a part of a good death. Studies show that terminally ill individuals experienced a "good death" if they actively participated in how, when, and where they chose to die $^{5}$. It was not until the 1980s when researchers and clinicians began to focus on issues related to death and dying (e.g. autonomy, palliative care, and dying with dignity) that the term "good death" moved beyond the confines of a synonym for euthanasia and was seen as a complex and individualized phenomena. Previous findings reveal that the characteristics of a good death differ among age groups $s^{3,6}$, men and women $^{7}$, patients ${ }^{8}$ and clinicians.But no research has been done regarding what a good death is in Sri Lanka. This study has been planned to fill that void.

\section{Objective}

The aim of the study is to identify the components of a good death in Ratnapura. 


\section{Methodology}

This qualitative, prospective serial study was done at General Hospital Ratnapura. The study sample included patients diagnosed as having life limiting illness and being followed up at the ENT, Palliative care and Oncology units. The study duration was 3 months starting from $1^{\text {st }}$ April 2015. Only patients giving written consent were included in the study. The study included in-depth interviews by trained medical officers while collecting their basic demographic information. Ethical clearance for the study was obtained from the National Institute of Health Sciences, Kalutara, Sri Lanka.

\section{Results}

There were 42 participants in the study. Their mean age was 61years (STD 12). It included $32(76 \%)$ males and $10(23.8 \%)$ females. Majority of them were married (41(97.6\%). Most of the patients (36(85.7\%) has had only secondary (up to Ordinary level) education. Thirty nine $(92.9 \%)$ said they were Buddhists while 3(7.1\%) said they were Hindus.

Thirty five $(83.33 \%)$ of the patients had cancer and $7(16.67 \%)$ had non cancer life limiting illness such as end stage organ failures and neurological diseases.

Patient's attributes of a good death obtained through the interview was divided in to fifteen categories (Table 1)
Table 1: Categories and their attributes

\begin{tabular}{|c|c|}
\hline Categories & Attributes \\
\hline $\begin{array}{l}\text { 1. Having a good family } \\
\text { relationship }\end{array}$ & $\begin{array}{l}\text { Having enough } \\
\text { time with one's } \\
\text { family } \\
\text { Having family } \\
\text { support } \\
\text { Having family by } \\
\text { one's side when } \\
\text { one is going to die } \\
\text { Being able to } \\
\text { express personal } \\
\text { feelings to one's } \\
\text { family members } \\
\text { Family is prepared } \\
\text { to one's death } \\
\text { Believing that } \\
\text { one's family will } \\
\text { do well after one's } \\
\text { death }\end{array}$ \\
\hline $\begin{array}{l}\text { 2. Having a good relationship } \\
\text { with medical staff }\end{array}$ & $\begin{array}{l}\begin{array}{l}\text { Discussing one's } \\
\text { treatment with } \\
\text { one's physician }\end{array} \\
\text { Having people who } \\
\text { can listen to one's } \\
\text { opinion/views } \\
\begin{array}{l}\text { Leaving all } \\
\text { decision making to } \\
\text { one's physician }\end{array} \\
\end{array}$ \\
\hline 3. Not being aware of death & $\begin{array}{l}\text { Dying as one sleeps } \\
\text { Living as usual } \\
\text { without thinking } \\
\text { about death } \\
\text { Dying without } \\
\text { awareness that one } \\
\text { is dying }\end{array}$ \\
\hline
\end{tabular}


ISSN : $2012-855 x$

Ceylon Journal of Otolaryngology

(C) 2015; College of Otorhinolaryngologists and Head and Neck Surgeons of Sri Lanka

\begin{tabular}{|c|c|}
\hline 4. Fighting against the disease & $\begin{array}{l}\text { Believing that one } \\
\text { used all available } \\
\text { treatments } \\
\text { Fighting against } \\
\text { disease until one's } \\
\text { last moment } \\
\begin{array}{l}\text { Living as long as } \\
\text { possible }\end{array}\end{array}$ \\
\hline $\begin{array}{l}\text { 5. Dying at ones favourite } \\
\text { place or environment }\end{array}$ & $\begin{array}{l}\text { Being able to stay } \\
\text { at one's favorite } \\
\text { place } \\
\text { Living like being at } \\
\text { home } \\
\text { Living in calm } \\
\text { circumstances }\end{array}$ \\
\hline 6. Having faith & \begin{tabular}{|lr} 
Feeling that one in \\
protected by ones \\
previous good \\
karma
\end{tabular} \\
\hline 7. Maintaining hope & $\begin{array}{l}\text { Having something } \\
\text { to enjoy } \\
\text { Living positively } \\
\text { Living in hope }\end{array}$ \\
\hline 8. Maintaining dignity & $\begin{array}{l}\text { Being respected for } \\
\text { one's values } \\
\text { Not being treated } \\
\text { as an object or a } \\
\text { child } \\
\text { Being free from } \\
\text { trivial routines }\end{array}$ \\
\hline $\begin{array}{l}\text { 9. Freedom from Pain \& } \\
\text { Physical symptoms }\end{array}$ & $\begin{array}{l}\text { Being free from } \\
\text { pain and physical } \\
\text { distress } \\
\text { Being calm }\end{array}$ \\
\hline $\begin{array}{l}\text { 10. Not being a burden to } \\
\text { others }\end{array}$ & $\begin{array}{l}\text { Having no financial } \\
\text { worries } \\
\text { Not being a burden } \\
\text { to family members } \\
\text { Not making trouble } \\
\text { for others }\end{array}$ \\
\hline
\end{tabular}

\begin{tabular}{|c|c|}
\hline $\begin{array}{l}\text { 11. Maintaining sense of } \\
\text { control }\end{array}$ & $\begin{array}{l}\text { Being independent } \\
\text { in daily activities } \\
\begin{array}{l}\text { Being mentally } \\
\text { clear }\end{array} \\
\text { Being able to eat } \\
\end{array}$ \\
\hline 12. Completion of life & $\begin{array}{l}\text { Being prepared for } \\
\text { dying } \\
\text { Family has no } \\
\text { regrets for one's } \\
\text { death } \\
\text { Having no regrets } \\
\text { for dying } \\
\text { Feeling one's life } \\
\text { being completed } \\
\end{array}$ \\
\hline 13. Appreciating others & $\begin{array}{l}\text { Seeing people } \\
\text { whom one wants } \\
\text { to see } \\
\text { Being reconciled } \\
\text { with people }\end{array}$ \\
\hline 14. Not to prolonging life & \begin{tabular}{|llll}
$\begin{array}{l}\text { Dying } \\
\text { death }\end{array}$ & & natural \\
& & \\
Not & & being \\
c o n n & e & c & e d d \\
with & medical \\
instruments & or \\
tubes &
\end{tabular} \\
\hline 15. Contributing to others & $\begin{array}{l}\text { Maintaining one's } \\
\text { role in family } \\
\text { or occupational } \\
\text { circumstances } \\
\text { Feeling that one } \\
\text { can contribute to } \\
\text { others } \\
\text { Feeling that one's } \\
\text { life is worth living }\end{array}$ \\
\hline
\end{tabular}

Eleven of these categories were mentioned by more than $50 \%$ of patients (Table 2 ). They were "Having a good family relationship", "Having a good relationship with medical staff", "Not being aware of death", "Fighting against the disease", "Dying at ones favourite place or environment", "Having faith", "Maintaining hope" 
and "Maintaining dignity". The most favoured dying place was home (Table 3), Three patients preferred the hospital and another three said that any place was good for their death.

Table 2: Categories of a good death in Ratnapura

\begin{tabular}{|l|c|c|}
\hline \multicolumn{1}{|c|}{ Categories } & Number & $\%$ \\
\hline $\begin{array}{l}\text { 1.Having a good fami- } \\
\text { ly relationship }\end{array}$ & 38 & $90.48 \%$ \\
\hline $\begin{array}{l}\text { 2. Having a good rela- } \\
\text { tionship with medical } \\
\text { staff }\end{array}$ & 31 & $73.81 \%$ \\
\hline $\begin{array}{l}\text { 3. Not being aware of } \\
\text { death }\end{array}$ & 29 & $69.05 \%$ \\
\hline $\begin{array}{l}\text { 4.Fighting against the } \\
\text { disease }\end{array}$ & 29 & $69.05 \%$ \\
\hline $\begin{array}{l}\text { 5. Dying at ones fa- } \\
\text { vourite place or envi- } \\
\text { ronment }\end{array}$ & 28 & $66.67 \%$ \\
\hline 6.Having faith & 27 & $64.29 \%$ \\
\hline 7. Maintaining hope & 27 & $64.29 \%$ \\
\hline 8. Maintaining dignity & 25 & $59.52 \%$ \\
\hline $\begin{array}{l}\text { 9. Freedom from Pain, } \\
\text { Physical \& Psycho- } \\
\text { logical symptoms }\end{array}$ & 24 & $57.14 \%$ \\
\hline $\begin{array}{l}\text { 10. Not being a burden } \\
\text { to others }\end{array}$ & 22 & $52.38 \%$ \\
\hline $\begin{array}{l}\text { 11. Maintaining sense } \\
\text { of control }\end{array}$ & 21 & $50 \%$ \\
\hline 12. Completion of life & 20 & $47.62 \%$ \\
\hline $\begin{array}{l}\text { 13. Appreciating oth- } \\
\text { ers }\end{array}$ & 15 & $35.71 \%$ \\
\hline $\begin{array}{l}\text { 14. Not to prolonging } \\
\text { life }\end{array}$ & 12 & $28.57 \%$ \\
\hline $\begin{array}{l}\text { 15. Contributing to } \\
\text { others }\end{array}$ & 12 & $28.57 \%$ \\
\hline
\end{tabular}

Table 3: Favourite place to die

\begin{tabular}{|l|l|}
\hline \multicolumn{1}{|c|}{ Place } & \multicolumn{1}{c|}{ Number } \\
\hline Home & $36(85.71 \%)$ \\
\hline Hospital & $3(7.14 \%)$ \\
\hline Any Place & $3(7.14 \%)$ \\
\hline
\end{tabular}

The categories least mentioned $(<50 \%)$ were "Completion of life", "Appreciating others", "Not to prolonging life" and "Contributing to others"

\section{Discussion}

This study identified attributes which were divided in to 15 categories as common components of “good death". The common components most often identified in Western literatures were pain and symptom control $^{9-11,13-19}$, family relationship ${ }^{9,11,13-17,19,20}$, not being a burden to others ${ }^{13,14,17}$, the sense of control $^{14,20}$, dignity ${ }^{9-11,18,20}$,environmental wellbeing ${ }^{13,15}$, preparation ${ }^{10,15,19}$, hope ${ }^{16}$,faith and spirituality ${ }^{13,16}$,contribution to others ${ }^{10,19}$,completion of life $\mathrm{e}^{10,13,19}$, good relationship with medical staff ${ }^{13,19,21}$ and avoidinginappropriate prolongation of life ${ }^{13,14}$. In the East especially studies in Japan has found some unique components which are prominently highlighted when compared to the west they are having a good relationship with medical staff, fighting against cancer, maintaining pride and Not being a burden to others ${ }^{12}$.

In this study $90.48 \%$ of the patients highlighted the importance of having a good family relationship. This may indicate the closeness and unity of a traditional Sri Lankan family and the availability of psychosocial and monetary support from these extended families.Another important fact identified during the interviews was unlike in western studies the autonomy in decision making was not considered important. They wanted a good relationship with medical staff $(73.81 \%)$. Many acknowledge their fondness to speak indepth about their condition with their physician and many wanted to continue with whatever treatment plan the physician has recommended. A study done before has shown that majority of Sri Lankan patients had no inhibition of accepting their diagnosis and its complications ${ }^{22}$ as such Sri Lankan patients wants to be informed about their diagnosis and prognosis but is happy to let the physician and family take decisions on treatment options. 
Fighting the disease was also mentioned in $69 \%$ interviews. They wanted taking all the available treatment options,this result would emphasizethat taking all the available treatments is an importantfactor for achieving good death in Sri Lanka. Not being aware of death was another component identified in $69 \%$ of the interviews. Many preferred to die during their sleep. Home was considered the best place to die.

Factors like freedom from pain, completion of life, not prolonging life and contributing to others were mentioned but many did not consider them essential for a good death.

\section{Conclusion}

This study tried to identify the important componentsof good death in Ratnapura,Sri Lanka. The main categories of good death were having a good family relationship, having a good relationship with medical staff, Not being aware of death, Fighting against the disease, Dying at ones favourite place, Having faith, Maintaining hope, Maintaining dignity, Freedom from Pain, Physical \& Psychological symptoms, Not being a burden to others and Maintaining sense of control. One main drawback of the study was the patients interviewed were mainly from a very low educational and socioeconomic level. Their views on a good death might not be the same as the general public in Ratnapura. A larger population study involving many hospitalsmay give a better understanding of a good death in Sri Lanka and its variations with factors such as age, sex and social level.

\section{Acknowledgments}

We wish to thank $\operatorname{Dr}(\mathrm{Mrs})$. L. Siriwardhana, Consultant Oncologist for giving permission to interview patients under her care.

\section{References}

1. Hooyman NR, Kiyak HA. Social Gerontology. Vol.6.Boston: Allyn\& Bacon; 2002.
2. Bassett J-F. Reaction time measures of death attitudes:examining the correlates of death anxiety and testing terror management hypotheses. Dissertation Abstracts International: Section $\mathrm{B}$ : The Sciences and Engineering, 63(6-B). Ann Arbor, MI: University Microfilms International; 2002.

3. Cicirelli VG. Personal meanings of death in older adults and young adults in relation to their fears of death.DeathStud. 2001;25(8):663683.

4. De Masi F. Making Death Thinkable: A Psychoanalytic Contribution to the Problem of the Transience of Life.London: Free Association; 2004.

5. Kehl KA. Moving toward peace: an analysis of the conceptof a good death.Am J HospPalliat Med. 2006;23(4):277-286.

6. Blum CA. 'Til death do us part?' The nurse's role in the care of the dead. A historical perspective: 1850-2004. GeriatrNurs. 2006;27(1):58-63.

7. Depaola SJ, Griffin M, Young JR, Neimeyer RA. Death anxiety and attitudes toward the elderly among adults: the role of gender and ethnicity. Death Stud. 2003; 27(4):335-354.

8.Vig EK, Davenport NA, Pearlman RA. Good deaths, bad deaths, and preferences for the end of life: a qualitativestudy of geriatric outpatients. J Am Geriatr Soc. 2002; 50:15411548.

9. Payne SA, Langley-Evans A, Hillier R. Perceptions of a 'good' death: a comparative study of the views of hospice staff and patients. Palliat Med 1996;10(4):307-312.

10. Steinhauser KE, Clipp EC, McNeilly M, et al. In search of a good death: observations of patients, families, and providers. Ann Intern Med 2000; 132(10):825-832. 
11. Patrick DL, Engelberg RA, Curtis JR. Evaluating the quality of dying and death. J Pain Symptom Managent 2001;22(3):717726.

12. Kei Hirai, Mitsunori Miyashita RN, Tatsuya Morita, Makiko Sanjo, Yosuke Uchitomi, Good Death in Japanese Cancer Care: A Qualitative Study. J Pain Symptom Management 2006:31(2):140-147.

13. Tong E, McGraw SA, Dobihal E, et al. What is a good death? Minority and non-minority perspectives. J Palliat Care 2003;19(3):168175.

14. Singer PA, Martin DK, Kelner M. Quality endof- life care: patients' perspectives. JAMA 1999; 281(2):163-168.

15. Dozor RB, Addison RB. Toward a good death: an interpretive investigation of family practice residents' practices with dying patients. Fam Med 1992;24(7):538-543. 146 Hirai et al. Vol. 31 No. 2 February 2006.

16. Emanuel EJ, Emanuel LL.The promise of a good death. Lancet 1998;351(Suppl 2): SII21-SII29.

17. Teno JM, Casey VA,Welch LC, EdgmanLevitan S. Patient-focused, family-centered end-of-life medical care: views of the guidelines and bereaved family members. J Pain Symptom Manage 2001;22(3): 738-751.

18. Cohen LM, Poppel DM, Cohn GM, Reiter GS. A very good death: measuring quality of dying in end- stage renal disease. J Palliat Med 2001;4(2):167-172.

19. Steinhauser KE, Bosworth HB, Clipp EC, et al. Initial assessment of a new instrument to measure quality of life at the end of life. $\mathrm{J}$ Palliat Med 2002; 5(6):829-841.

20. Enes SP. An exploration of dignity in palliative care.Palliat Med 2003;17(3):263-269.
21. Steinhauser KE, Christakis NA, Clipp EC, et al. Factors considered important at the end of life by patients, family, physicians, and other care providers.JAMA 2000;284(19):24762482.

22. Perera M.C., Tennakoon T.M.S., Kumarasiri L.A., Jayasinghe S.M.N.C., Rathnayake R.M.W.D., RajapakshaR.M.A.M.Cancer in Sri Lanka: The Question of, "To Tell or Not to Tell"Ceylon Journal of Otolaryngology 2013; 3(1):pp 17-19

\author{
Corresponding Author: ${ }^{1}$ \\ Dr. M. C. Perera, \\ Consultant ENT Surgeon, \\ General Hospital, \\ Ratnapura, \\ Srilanka. \\ E-mail:mcperera@gmail.com
}

